\title{
Effect of harvest date and seed type on green-shell and dry bean yield ${ }^{1,2}$
}

\author{
James S. Beaver ${ }^{3}$ \\ J. Agric. Univ. P. R. 84(1-2):29-34 (2000)
}

\begin{abstract}
In Puerto Rico, harvesting beans (Phaseolus vulgaris L.) near physiological maturity enhances the value of the crop. Whole-pod yields greater than $5,000 \mathrm{~kg} / \mathrm{ha}$ were obtained from bean lines harvested about 65 days after planting. Whole-pod yields of the white bean cultivar Arroyo Loro were equal to or greater than those of bean breeding lines with different seed types. However, the green-shell seed yield of the small red line DOR364 was greater than that of Arroyo Loro. The small red line DOR364 achieved greater green-shell seed yields by partitioning a greater portion of wholepod weight into green-shell seed weight. Whole pod and green-shell bean yields were more consistent over years and locations than dry bean yields. Whole pod yields of beans harvested at the green-shell and semi-dry stages of development were similar, thus suggesting that harvest could be delayed as much as one week after the appearance of the first brown pod without losing green-shell bean yield.
\end{abstract}

Key words: Phaseolus vulgaris L., stage of development, harvest

\section{RESUMEN}

Efecto de la fecha de cosecha y del tipo de semilla en el rendimiento de la habichuela verde y seca

En Puerto Rico, la cosecha de habichuela (Phaseolus vulgaris L.) cerca de su madurez fisiológica aumenta el valor del cultivo. Se obtuvieron rendimientos de vainas verdes enteras mayores de $5,000 \mathrm{~kg} / \mathrm{ha}$ de líneas de habichuela que se cosecharon aproximadamente 65 días después de la siembra. Los rendimientos promedios del cultivar blanco Arroyo Loro fueron iguales - mayores que los rendimientos de las otras líneas con diferentes colores de semilla. Sin embargo, los rendimientos de semilla verde de la línea rojo pequeño DOR364 fueron mayores que los de Arroyo Loro. DOR364 logró un mayor rendimiento de semilla verde a través de una distribución mayor del peso de las vainas hacia el peso de la semilla. Los rendimientos de vainas enteras y semilla verde fueron más estables que los rendimientos de semilla seca. Los rendimientos de vainas enteras y semilla verde fueron similares cuando se cosechó en las etapas de habichuela verde y semi-seca. Estos resultados sugieren que se puede esperar a cosechar hasta una semana después de aparecer la primera vaina seca sin sufrir una pérdida en rendimiento de semilla verde.

${ }^{2}$ Manuscript submitted to the Editorial Board 24 June 1999.

2This research was supported by Puerto Rico Agricultural Experiment Station CSREES/TSTAR Project CBAG-46 entitled "Processing and Preservation of green-shelled beans (Phaseolus vulgaris L.)".

"Researcher, Department of Agronomy and Soils, University of Puerto Rico, P.O. Box 9030, Mayagüez, PR 00680-9030. E-mail:__beaver@rumac.upr.clu.edu. 


\section{INTRODUCTION}

Beans (Phaseolus vulgaris L.) in Puerto Rico are harvested near physiological maturity as a means of enhancing the value of the crop. Farmers often receive as much as $\$ 2.20 / \mathrm{kg}$ for whole-pods of beans harvested near physiological maturity whereas the price for dry beans is less than $\$ 1.00 / \mathrm{kg}$. In 1997 , more than 800 ha of green-shell beans was planted throughout the island (M. Cortés, Assistant Economist, Agricultural Experiment Station, University of Puerto Rico, Mayaguiez, Puerto Rico, personal communication). Badillo et al. (1985) noted that additional advantages of green-shell bean production were a reduction in number of days from emergence to harvest, less effect of adverse weather on the quality of the crop, and escape from disease and insect damage that may occur during the end of the growing season. Kays et al. (1980) noted that green-shell bean production permits the second crop in a multiple cropping sequence to be planted earlier. A potential disadvantage of green-shell bean production is the need to market the perishable crop within a few days after harvest. González et al. (1982), however, found that green-shelled beans stored for $24 \mathrm{~h}$ at $27^{\circ} \mathrm{C}$ before canning received sensory panel evaluations similar to those of dry beans.

Román-Hernández and Beaver (1997) studied the effect of planting date on the production of green-shell beans in Puerto Rico. The greatest whole-pod and green-shelled bean yields were produced when beans were planted in October and November, when temperatures begin to decline. Beans planted during the warm and humid summer months from May to August yielded the least. However, fresh market prices during the summer months are higher because green-shell pigeon peas [Cajanus cajan L. (Huth)] are not available.

Stage of development at harvest can affect the yield and quality of the green-shell bean crop. Cerna and Beaver (1989) reported that physiological maturity of indeterminate red and white beans occurred when the first pod on the plant turned brown. However, Román-Hernández and Beaver (1997) found that harvesting at physiological maturity reduced both the yield and quality of green-shell beans. The most appropriate time to harvest green-shell beans was found to be when a large number of pods had become yellow but before the appearance of brown pods. In Puerto Rico, this stage occurs between 60 to 65 days after planting for white bean cultivars such as Arroyo Loro and Morales.

Although white beans are used in Puerto Rico for green-shell bean production, knowledge of the performance of bean lines having other seed types would be helpful for the choice of parents in a bean-breeding program. Therefore, the first objective of this research was to compare 
whole-pod and green-shell bean yields of the white bean cultivar Arroyo Loro with yields of breeding lines that have different seed types. A better understanding of the effect of stage of harvest on green-shell bean yield would permit more effective evaluation of bean lines for this trait. Thus, the second objective was to measure the effect of harvest date on yield and quality of green-shelled beans.

\section{MATERIALS AND METHODS}

\section{Variety trial}

Four field experiments were planted at the Isabela and Fortuna Substations over a two-year period to compare whole-pod and greenshell bean yield after different planting dates. The experiments were planted at Isabela in October 1992 and January 1993. At Fortuna, the experiments were planted in January 1992 and 1993. A randomized complete block design with four replications was used. Five bean lines with different seed types were evaluated. Arroyo Loro is a white-seeded bean, PR9180-25 is a red mottled bean, DOR364 has small red seed, PR9156-61 is a pink bean line and PR9226-5 is a pinto bean. Experimental units consisted of two four-meter rows spaced $0.6 \mathrm{~m}$ apart. The beans were planted at a rate of 200,000 seed/ha. Green-shell beans were harvested after yellow pods developed but before brown pods appeared (Román-Hernández and Beaver, 1997). Whole-pod and greenshell seed weights were recorded for each experimental unit. Results were analyzed in an analysis of variance, and means were compared by using Least Significant Differences (0.05).

\section{Harvest date study}

Field experiments were planted at the Isabela and Fortuna Substations in October 1991, October 1992 and January 1993. A randomized complete block design with three replications was used. Experimental units consisted of four-meter rows spaced $0.6 \mathrm{~m}$ apart. The white bean cultivar Arroyo Loro was planted at the rate of 200,000 seed/ha. The green-shell beans were harvested after yellow pods developed but before brown pods appeared. The semi-dry harvest was made seven to 10 days after the green-shell harvest, when several pods had turned brown. The dry bean harvest was conducted when all the pods had dried. Fresh whole pod weights were measured for the green-shell and semi-dry harvests. Fresh seed weights were measured for all three harvest treatments. Results were analyzed in an analysis of variance, and means were compared by using Least Significant Differences (0.05). 


\section{RESULTS AND DISCUSSION}

Mean whole-pod yields at Isabela were similar both years whereas at Fortuna, the 1992 whole-pod yields were greater than the 1993 yields (Table 1). Most of the lines produced whole-pod mean yields greater than $5,000 \mathrm{~kg} / \mathrm{ha}$ in all environments. The whole-pod yields of the white bean cultivar Arroyo Loro were equal to or greater than those of lines with different seed types (Table 1). Whole-pod yields of the small red line DOR364 and the pink line PR9156-61 were similar to that of the white seeded check cultivar Arroyo Loro. The determinate red mottled line PR9180-25 produced the lowest whole-pod yields whereas the pinto line PR9226-5 showed the most variability over locations and years (Table 1).

Mean green-shell seed yields were similar over years and locations, ranging from 2,260 to $2,514 \mathrm{~kg} / \mathrm{ha}$ (Table 2). The green-shell seed yield of DOR364 was greater than that of Arroyo Loro at both Fortuna and Isabela. DOR364 achieved greater green-shell seed yields than Arroyo Loro by partitioning a greater portion of whole-pod weight into greenshell seed weight. This line, which is resistant to bean golden mosaic virus, should be considered as a parent to improve the green-shell yield of white beans. Green-shell yields of the red mottled, pink and pinto lines were similar to the yield of Arroyo Loro across years and locations (Table 2).

Whole-pod and green-shell seed yields of Arroyo Loro were similar over years and locations (Table 3). However, green-shell seed yields were more consistent over years and locations than dry bean yields. These results suggest that harvesting beans at the green-shell stage of development would provide farmers with a more reliable source of in-

TABLE 1.-Whole-pod bean yield of six bean lines evaluated at the Isabela and Fortuna Substations in 1992 and 1993.

\begin{tabular}{|c|c|c|c|c|c|c|}
\hline \multirow[b]{2}{*}{ Line } & \multirow[b]{2}{*}{ Seed type } & \multicolumn{2}{|c|}{ Isabela } & \multicolumn{2}{|c|}{ Fortuna } & \multirow[b]{2}{*}{ Mean } \\
\hline & & Oct. 1992 & Jan. 1993 & Jan. 1992 & Jan. 1993 & \\
\hline Arroyo Loro & White & 6,249 & 7,037 & 9,181 & 5,487 & 6,989 \\
\hline PR9180-25 & Red mottled & 4,886 & 5,487 & 7,390 & 5,129 & 5,723 \\
\hline DOR 364 & Small red & 5,378 & 6,202 & 9,032 & 6,739 & 6,838 \\
\hline PR9156-61 & Pink & 6,628 & 6,560 & 7,166 & 6,441 & 6,699 \\
\hline PR9226-5 & Pinto & 4,355 & 6,083 & 10,897 & 4,770 & 6,526 \\
\hline Mean & & 5,499 & 6,274 & 8,733 & 5,713 & \\
\hline $\operatorname{LSD}(0.05)$ & & 1,444 & 1,066 & 1,785 & 1,145 & \\
\hline
\end{tabular}


TABLE 2.-Green-shell seed yield of six bean lines evaluated at the Isabela and Fortuna Substations in 1992 and 1993.

\begin{tabular}{|c|c|c|c|c|c|c|}
\hline \multirow[b]{2}{*}{ Line } & \multirow[b]{2}{*}{ Seed type } & \multicolumn{2}{|c|}{ Isabela } & \multicolumn{2}{|c|}{ Fortuna } & \multirow[b]{2}{*}{ Mean } \\
\hline & & Oct. 1992 & Jan. 1993 & Jan. 1992 & Jan. 1993 & \\
\hline & & & & - kg/ha . & & \\
\hline Arroyo Loro & White & 1,625 & 1,679 & 2,259 & 1,860 & 1,856 \\
\hline PR9180-25C & Red mottled & 2,028 & 2,462 & 1,976 & 2,511 & 2,244 \\
\hline DOR 364 & Small red & 2,880 & 3,321 & 3,082 & 2,464 & 2,937 \\
\hline PR9156-61 & Pink & 2,897 & 2,095 & 2,511 & 2,770 & 2,568 \\
\hline PR9226-5 & Pinto & 1,873 & 2,678 & 2,743 & 1,930 & 2,306 \\
\hline Mean & & 2,260 & 2,447 & 2,514 & 2,307 & \\
\hline $\operatorname{LSD}(0.05)$ & & 682 & 522 & 534 & 492 & \\
\hline
\end{tabular}

come. Similar whole-pod yields obtained from beans harvested at the green-shell and semi-dry stages of development suggest that farmers would have some flexibility in harvesting green-shelled beans (Table 3 ). Harvest could be delayed as much as one week after the appearance of the first brown pod without losing whole-pod yield. However, beans harvested at a later date would have a greater portion of brown pods, which might reduce the fresh-market value of the crop. Kays et al. (1980) reported that the yield of dark red kidney beans harvested in the pre-dry stage of development was not significantly reduced. Acceptable yields of green-shell and dry beans were obtained at both the Isabela and Fortuna Substations (Table 3). These results are in agreement

TABLE 3.-Whole-pod and seed yield of the white bean Arroyo Loro harvested at three stages of development in trial planted at the Isabela and Fortuna Substations from 1991 to 1993.

\begin{tabular}{|c|c|c|c|c|c|c|c|}
\hline & \multirow{2}{*}{$\begin{array}{c}\text { Stage of } \\
\text { development }\end{array}$} & \multicolumn{3}{|c|}{ Isabela } & \multicolumn{3}{|c|}{ Fortuna } \\
\hline & & 1991 & 1992 & 1993 & 1991 & 1992 & 1993 \\
\hline & & 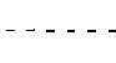 & 更 & - & $a=$ & - & \\
\hline \multirow[t]{3}{*}{ Whole-pod } & Green-shell & 6,296 & 6,869 & 6,918 & 7,870 & 7,103 & 6,978 \\
\hline & Semi-dry & 6,981 & 6,563 & 6,127 & 8,726 & 5,740 & 7,808 \\
\hline & $\operatorname{LSD}(0.05)$ & N.S. & N.S. & N.S. & N.S. & N.S. & N.S. \\
\hline \multirow[t]{4}{*}{ Seed } & Green-shell & 3,487 & 2,109 & 3,240 & 3,512 & 3,869 & 3,159 \\
\hline & Semi-dry & 3,303 & 2,158 & 3,211 & 4,552 & 2,993 & 3,608 \\
\hline & Dry & 1,987 & 1,461 & 1,751 & 1,122 & 1,826 & 1,508 \\
\hline & LSD (0.05) & 1,053 & 363 & 695 & 1,382 & 1,053 & 645 \\
\hline
\end{tabular}


with those of González et al. (1982), who concluded that green-shell bean production should be feasible. Farmers and processors with experience in canning cowpea (Vigna unguiculata) or pigeon pea might find green-shell bean production to be a viable alternative.

\section{LITERATURE CITED}

Badillo-Feliciano, J., I. R. Soto and J. S. Beaver, 1985. A comparison of yields of common beans at physinlogical and harvest maturity. J. Agric: Univ. P.R. 69:19-24.

Cerna, $J$. and J.S. Beaver, 1989. A visual indicator of the physiological maturity stage of development. J. Agric. Univ. P.R. 73:361-365.

González, A. R., K. M. Edwards and D. B. Marx, 1982. Storage and processing quality of beans (Phaseolus vulgaris L.) harvested at the semi-dry stage. J. Amer: Soc. Hort. Sci. 107:82-86.

Kays, S. J., J. W. Williams and D. R. Davis, 1980. Harvest of dry beans in the pre-dry stage of development: Effect of yield and processed product quality. J. Amer: Soc. Hort. Sci. 105:15-17.

Román-Hernández, O. and J. S. Beaver, 1997. Optimum stage of development for harvesting green-shelled beans. J. Agric. Univ. P.R. 80:89-94. 